\title{
Luftsichel sign
}

\author{
Sankar Neelakantan, Rakesh Anandarajan, Anil Kumar Swamy, Ravi Hoisala
}

Department of Radiology, St Johns Medical College and Hospital, Bangalore, Karnataka, India

\section{Correspondence to} Dr Sankar Neelakantan, dr.sankar@live.com

Accepted 11 June 2016

\section{DESCRIPTION}

A 58-year-old man presented with cough and haemoptysis of 3 -week duration. Screening chest radiograph revealed a veil-like homogenous opacity over the left lung field extending out from the hilum and fading out inferiorly. The aortic knuckle was silhouetted by an adjacent hyperlucent air crescent. These findings are suggestive of the Luftsichel sign (figures 1 and 2).

Contrast-enhanced multidetector CT of the chest showed a left hilar enhancing soft tissue mass causing complete occlusion of the left upper lobe bronchus, resulting in left upper lobar collapse. Compensatory hyperinflation of the superior segment of the left lower lobe was noted to insinuate itself between the superior mediastinum and the collapsed left upper lobe (figures 3 and 4).

'Luftsichel' is a German word that means air crescent (luft means air, sichel means sickle). It is seen in upper lobe collapse, more commonly of the left rather than right upper lobe. The sign is noted in posteroanterior chest radiographs as a hyperlucent shadow extending from the apical lobe to the superior pulmonary vein, and sandwiched between the aorta medially and the medial aspect of the collapsed upper lobe laterally. ${ }^{1}$

The upper lobe collapses in the anterosuperior direction to lie parallel to the anterior chest wall. Therefore, the posterior empty space is filled by the hyperexpanded superior segment of the lower lobe, which gives rise to the hyperlucency around the aortic knuckle.

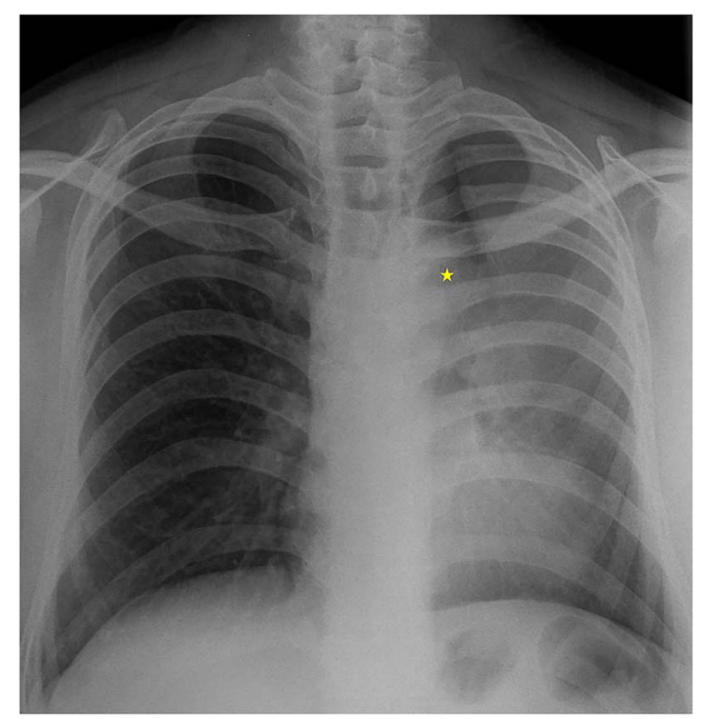

Figure 1 Frontal radiograph showing a veil-like homogenous opacity over the left lung field extending out from the hilum and fading out inferiorly. The aortic knuckle (star) is silhouetted by an adjacent hyperlucent air crescent. These findings are suggestive of the Luftsichel sign.

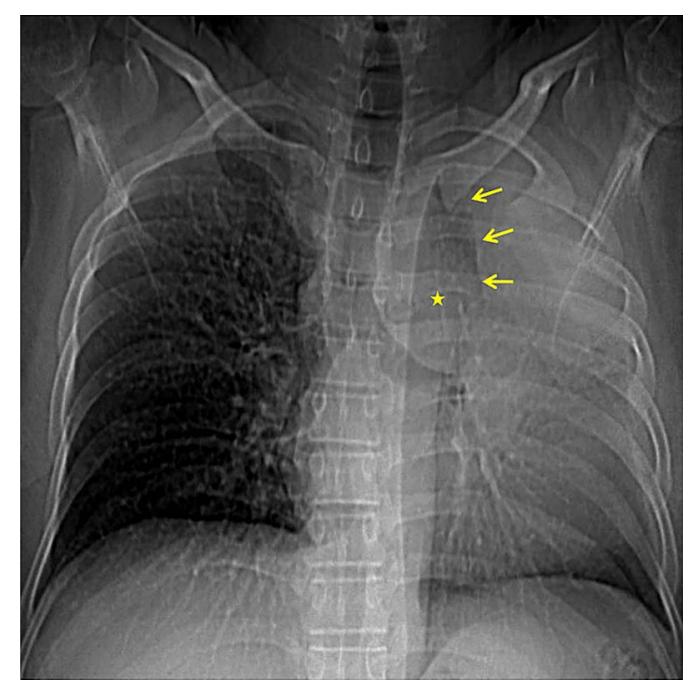

Figure 2 CT scannogram (penetrated radiograph) clearly delineating the air crescent (arrows) outlining the aortic knuckle (star).

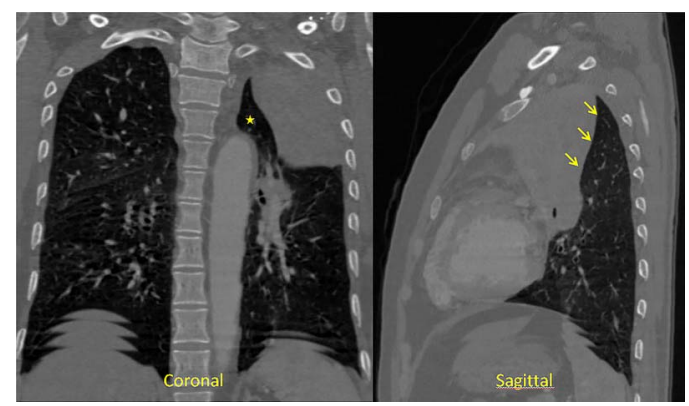

Figure 3 Coronal and sagittal sections of the contrast-enhanced CT of the chest showing a collapsed left upper lobe pulling the major fissure anterosuperiorly (arrows) and compensatory hyperinflation of the superior segment of the left lower lobe (star), which is noted to insinuate itself between the superior mediastinum and the collapsed left upper lobe.

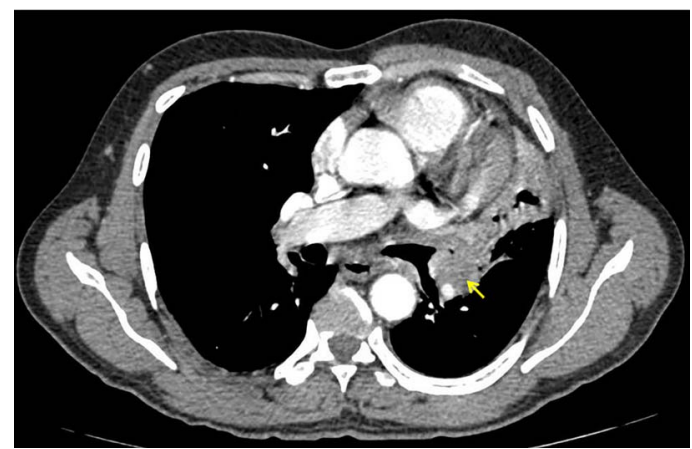

Figure 4 Axial section of the contrast-enhanced CT of the chest showing a left hilar enhancing soft tissue mass causing complete occlusion of the left upper lobe bronchus. 


\section{Learning points}

- 'Luftsichel' is a German word that means air crescent (luft means air, sichel means sickle). It is seen in upper lobe collapse, more commonly of the left rather than the right upper lobe.

- The differential diagnosis for the Luftsichel sign includes herniation of the right lung and mediastinal pneumothorax.

The differential diagnosis for the Luftsichel sign includes herniation of the right lung and mediastinal pneumothorax. In right lung herniation, the lung herniates retrosternally to produce a parasternal hyperlucency. Whereas, in mediastinal pneumothorax, there would be no other signs of collapse and there may be pneumothorax or subcutaneous emphysema accompanying it. Therefore, both conditions can be differentiated from left upper lobe collapse producing the Luftsichel sign. ${ }^{2}$

Twitter Follow Sankar Neelakantan at @drsankar23

Contributors SN contributed in the concept and drafting of the manuscript. RA was involved in editing. AKS contributed in providing the pictures. $\mathrm{RH}$ contributed in final approval of the manuscript.

Competing interests None declared.

Patient consent Obtained.

Provenance and peer review Not commissioned; externally peer reviewed.

\section{REFERENCES}

1 Blankenbaker DG. The luftsichel sign. Radiology 1998;208:319-20.

2 Singh S, Singh N, Tikkiwal S. Luftsichel sign. Lung India 2012;29:83-4.

Copyright 2016 BMJ Publishing Group. All rights reserved. For permission to reuse any of this content visit http://group.bmj.com/group/rights-licensing/permissions.

BMJ Case Report Fellows may re-use this article for personal use and teaching without any further permission.

Become a Fellow of BMJ Case Reports today and you can:

- Submit as many cases as you like

- Enjoy fast sympathetic peer review and rapid publication of accepted articles

- Access all the published articles

- Re-use any of the published material for personal use and teaching without further permission

For information on Institutional Fellowships contact consortiasales@bmjgroup.com

Visit casereports.bmj.com for more articles like this and to become a Fellow 